\title{
EVALUATION OF ANTI-ASTHMATIC ACTIVITY OF CAPPARIS DECIDUA
}

\author{
RAJSHREE DAHIYA*, JAI SINGH VAGHELA
}

Department of Pharmacology, B. N. University, Udaipur, Rajasthan, India. Email: dahiyarajshree7@gmail.com

Received: 14 October 2021, Revised and Accepted: 10 January 2022

\begin{abstract}
Objective: The present study was conducted to determine the anti-asthmatic activity of Capparis decidua.

Methods: The acute oral toxicity study was conducted as per OECD guidelines, and the extract was proved to be safe up to the dose of 2000 mg/kg. The anti-asthmatic activity of $C$. decidua was evaluated using various experimental models such as histamine-induced bronchoconstriction in guinea pigs and milk-induced leukocytosis in mice, histamine-induced bronchospasm in guinea pigs, studies on pre convulsive time and milk-induced leukocytosis in mice, studies on blood.
\end{abstract}

Results: Antihistaminic drugs Chlorpheniramine maleate and ethanolic extract of $C$. decidua significantly protected the guinea pigs against histamineinduced bronchospasm. The ethanolic section of $C$. decidua has dramatically prolonged the latent period of convulsions compared to control. Ethanolic extract of $C$. decidua suppresses the milk-induced leukocytosis by stabilizing the oxidative stress in the surrounding tissue.

Conclusion: The results obtained in the above study suggest the ethanolic extract of $C$. decidua possesses significant anti-asthmatic activity.

Keywords: Asthma, Capparis decidua, Histamine, Bronchoconstriction, Leukocytosis.

(C) 2022 The Authors. Published by Innovare Academic Sciences Pvt Ltd. This is an open access article under the CC BY license (http://creativecommons.org/ licenses/by/4.0/) DOI: http://dx.doi.org/10.22159/ajpcr.2022v15i2.43378. Journal homepage: https://innovareacademics.in/journals/index.php/ajpcr

\section{INTRODUCTION}

Asthma is an allergic reaction that causes inflammation and narrowing of the respiratory tract, resulting in asthma and difficulty in breathing [1]. Asthma is the common chronic inflammatory disease of the airways characterized by frequent and recurrent symptoms, reversible airflow obstruction, and bronchospasm. Asthma is caused by various factors such as allergens, drugs, respiratory infection, dust, cold air, exercise, emotions, occupational stimuli, chemicals, histamine, etc. It is thought to be caused by a combination of genetic factors, environmental factors (such as tobacco, hygiene hypothesis, and volatile organic compounds), genetic interactions, exacerbation, social and economic factors [2-5]. Asthma is characterized by inflammatory cells in the air, including eosinophils, macrophages, mast cells, epithelial cells, and activated lymphocytes that release various cytokines, adhesion molecules, and other mediators. Inflammation results in an acute, sub-acute or chronic process that alters airway tone, modulates vascular permeability, activates nerves, increases secretion of mucus, and alters the structure of the airway by reversibly or permanently [1]. Asthma is a major public health problem worldwide [6]. There has been a dramatic increase in global prevalence, illness, death, and financial burden associated with asthma over the past 40 years, nearly 300 million people worldwide are currently suffering from asthma, and its prevalence is increasing by $50 \%$ every decade [7]. The highest rate of asthma are found in the United Kingdom (>15\%), New Zealand (15.1\%), Australia (14.7\%), the Republic of Ireland (14.6\%), Canada (14.1\%), and United States (10.9\%). One person in 10 has asthma in North America, Approximately, 35.5 million people [7]. The large number of drugs is used for the treatment of asthma. At present, available treatment for asthma most medications works by relaxing bronchospasm or reducing inflammation. These available treatments are not efficient for treating asthma completely as they have many toxic and side effects. The Ayurveda suggests that herbal plants have comparatively less toxic value and are more efficacious. They also have fewer chances of side effects and complications to patients compared to available synthetic drug treatments [1]. Capparis decidua belongs to the family Capparaceae $[8,9]$. The effects of the ethanolic extract of $C$. decidua may be due to the presence of phytochemicals such as flavonoids, saponins, steroids, alkaloids, glycoside, and tannins, known to have similar effects. Isocodonocarpine was found to be responsible for anti-inflammatory activity and anti-asthmatic activity [9-15].

\section{METHODS}

Plant collection and authentication

The collection of the leaves of $C$. decidua was done in January from the Jodhpur region, Rajasthan. As plants will be enriched with phytoconstituents at that time. Identification and authentication of the plants were carried out by Dr. S. L. Meena Scientist D \& Botanical survey of India, Jodhpur (Raj) (No.:BSI/AZRC/I.12012/Tech./2019-20/ PI.Id/235).

\section{Preparation of plant extract}

The leaves of $C$. decidua were washed and dried under shade for 25 days. The leaves were cleaned and grind with the help of a grinder. After proper milling, the weight of the powder was measured. Powder was used for the soxhlet extraction. About $130 \mathrm{~g}$ of dried powder was extracted with petroleum ether in soxhlet apparatus for 18-20 h at $60-80^{\circ} \mathrm{C}$ to the powder, and then mark was extracted with benzene (for $15-16 \mathrm{~h}$ at $78-80^{\circ} \mathrm{C}$ ), chloroform (for $15-16 \mathrm{~h}$ at $60-62^{\circ} \mathrm{C}$ ), and ethanol (for $16-18 \mathrm{~h}$ at $75-79^{\circ} \mathrm{C}$ ). The extract at the bottom was collected, and the solvents were removed using reflex condenser and dried on the water bath. Each time, before the extraction with other solvents, the powdered substance is air-dried. Percentage (\%) yield was found for petroleum ether extract was $6.69 \%$, benzene extract was $3.44 \%$, chloroform extract was 3.85\%, and ethanolic extract was $7.75 \%$. Obtained extracts were subjected to phytochemical investigation.

\section{Experimental animals}

Dunkin-Hartley guinea pig (350-400 g) and albino mice (20-30 g) of both sexes were housed together in a group of four in clean polypropylene cages (males separated from females). Bedding material of the cages was changed from time to time. Animals were cared for under standard environment conditions (12 h light: $12 \mathrm{~h}$ dark cycle, $22 \pm 3^{\circ} \mathrm{C}$ temperature, and $30-70 \%$ humidity). One-week time was provided to the animals for acclimatization with our laboratory 
Table 1: Qualitative chemical analysis of petroleum ether, chloroform, benzene, and ethanolic extract of Capparis decidua

\begin{tabular}{|c|c|c|c|c|c|}
\hline \multirow[t]{2}{*}{ S. No. } & \multirow[t]{2}{*}{ Test for plant constituents } & \multicolumn{4}{|l|}{ Capparis decidua root } \\
\hline & & Petroleum ether extract & Benzene extract & Chloroform extract & Ethanolic extract \\
\hline \multirow[t]{5}{*}{1.} & Test for carbohydrate & & & & \\
\hline & Molish test & - & + & + & + \\
\hline & Fehling's test & - & + & + & + \\
\hline & Benedict's test & - & + & + & + \\
\hline & Barfoed's test & - & + & + & + \\
\hline \multirow[t]{4}{*}{2.} & Test for protein & & & & \\
\hline & Biuret test & - & - & - & + \\
\hline & Million's test & - & - & - & + \\
\hline & Ninhydrin test & - & - & - & + \\
\hline \multirow[t]{4}{*}{3.} & Test for Alkaloids & & & & \\
\hline & Mayer's test & - & - & - & + \\
\hline & Dragenoff's test & - & - & - & + \\
\hline & Wagner's test & - & - & - & + \\
\hline \multirow[t]{3}{*}{4.} & Test for Fats and Oils & & & & \\
\hline & Spot test & + & - & - & - \\
\hline & Saponification test & + & - & - & - \\
\hline \multirow[t]{5}{*}{5.} & Test for glycoside & & & & \\
\hline & Legal test & - & - & - & + \\
\hline & Baljet's test & - & - & - & + \\
\hline & Borntrager's test & - & - & - & + \\
\hline & Foam test & - & - & - & + \\
\hline \multirow[t]{3}{*}{6.} & Test for Flavonoids & & & & \\
\hline & Ferric chloride test & - & - & - & + \\
\hline & Shinoda's test & - & - & - & + \\
\hline \multirow[t]{3}{*}{7.} & Test for Tannins and phenolic compounds & & & & \\
\hline & Ferric chloride test & - & - & - & + \\
\hline & Reaction with lead acetate & - & - & - & + \\
\hline \multirow[t]{2}{*}{8.} & Steroids & & & & \\
\hline & Libermann's Burchard test & - & - & - & + \\
\hline
\end{tabular}

Table 2: Percentage protection against histamine-induced bronchoconstriction in guinea pigs at different time intervals

\begin{tabular}{|c|c|c|c|c|c|c|c|c|}
\hline \multirow[t]{3}{*}{ S. No. } & \multirow[t]{3}{*}{ Group $N=6$} & \multicolumn{4}{|c|}{ Pre convulsion dyspnea (in sec) (Mean \pm SEM) } & \multicolumn{3}{|c|}{$\%$ Protection } \\
\hline & & \multirow[t]{2}{*}{ Before treatment } & \multicolumn{3}{|c|}{ After treatment } & \multirow[t]{2}{*}{$1 \mathrm{~h}$} & \multirow[t]{2}{*}{$4 \mathrm{~h}$} & \multirow[t]{2}{*}{$24 \mathrm{~h}$} \\
\hline & & & $1 \mathrm{~h}$ & $4 \mathrm{~h}$ & $24 \mathrm{~h}$ & & & \\
\hline 1. & Group-I & $16.43 \pm 0.20$ & - & - & - & - & - & - \\
\hline 2. & Group-II & $16.24 \pm 0.28$ & $55.66 \pm 0.40^{* *}$ & $69.55 \pm 0.21^{* *}$ & $25.5 \pm 0.14^{* *}$ & 70.83 & 76.65 & 36.32 \\
\hline 3. & GROUP-III & $14.35 \pm 0.28$ & $30.41 \pm 0.83^{* *}$ & $41.1 \pm 0.25^{* *}$ & $18.11 \pm 0.42^{* *}$ & 52.82 & 65.09 & 20.77 \\
\hline
\end{tabular}

Data are expressed as mean \pm SEM. Where, $\mathrm{n}=6$. Statistical analysis was done by ANOVA followed by Dunnett's test, where *p $<0.01, * * \mathrm{p}<0.05$ when Groups II and III were compared with Group I. Group-I (Control): Aerosolized Histamine (0.2\% w/v) + Phosphate buffer (1 mL/kg, p.o.) Group-II (Std.): Aerosolized Histamine (0.2\% w/v) + Chlorpheniramine maleate ( $2 \mathrm{mg} / \mathrm{kg}$, i.p.). Group-III (Test): Aerosolized Histamine $(0.2 \% \mathrm{w} / \mathrm{v})+$ Ethanolic extract of $C$. decidua (200 mg/kg, p.o.).

Table 3: Effect of ethanolic extracts of Capparis decidua on milk-induced leukocytosis in mice

\begin{tabular}{|c|c|c|}
\hline S. No. & $\begin{array}{l}\text { Group } \\
n=6\end{array}$ & $\begin{array}{l}\text { Difference in number of leucocytes } \\
\text { (per cumm) (Mean } \pm \text { SEM) }\end{array}$ \\
\hline 1. & Group-I & $1.50 \pm 21.39$ \\
\hline 2. & Group-II & $6883.34 \pm 47.85$ \\
\hline 3. & Group-III & $2975 \pm 53.87^{* *}$ \\
\hline 4. & Group-IV & $3700 \pm 75.22^{* *}$ \\
\hline \multicolumn{3}{|c|}{$\begin{array}{l}\text { Data are expressed as mean } \pm \text { SEM Where, } \mathrm{n}=6 \text {. Statistical analysis was done by } \\
\text { ANOVA followed by Dunnett's test, where }{ }^{*} \mathrm{p}<0.01,{ }^{* *} \mathrm{p}<0.05 \text { when Groups II, III, } \\
\text { and IV were compared with Group I. Group-I (Normal Control): Distilled water } \\
10 \mathrm{~mL} / \mathrm{kg} \text {, p.o. Group-II (Positive control): Boiled and cooled milk }(4 \mathrm{~mL} / \mathrm{kg} \text {, s.c.) } \\
\text { Group-III (Std.): Dexamethasone ( } 50 \mathrm{mg} / \mathrm{kg} \text {, i.p.) + Boiled and cooled milk } \\
\text { ( } 4 \mathrm{~mL} / \mathrm{kg} \text {, s.c.). Group-IV (Test): Boiled and cooled milk ( } 4 \mathrm{~mL} / \mathrm{kg} \text {, s.c.) } \\
+ \text { Ethanolic extract of } C \text {. decidua ( } 200 \mathrm{mg} / \mathrm{kg} \text {, p.o.) }\end{array}$} \\
\hline
\end{tabular}

environment. Animals were fasted 3-4 h before dosage but allowed free access to drinking water and standard pelleted diet ad libitum. Experimental protocol was approved by the Institutional Animal Ethics Committee (IAEC) Reg. no.16/BNCP/IAEC/2021.
Acute toxicity study

The dose was selected using an acute toxicity study (OECD, 423). The acute toxicity study for ethanolic extract of $C$. decidua was performed using mice. The animals were free access to food and water before the experiment and maintained under standard conditions. Find the $\mathrm{LD}_{50}$ of ethanolic extract of $C$. decidua, three groups of mice, containing three in each group, were given $C$. decidua in the dose of $2000 \mathrm{mg} / \mathrm{kg}$ orally. The animals were monitored for 5 min every $30 \mathrm{~min}$ up to $2 \mathrm{~h}$, and then at 4,8 and $24 \mathrm{~h}$ after treatment for any behavioral changes/death. They were also monitored daily for 14 days for death. No deaths occurred within 14 days after the ethanolic treatment of $C$. decidua was observed and was therefore found to be safe up to a dose of $2000 \mathrm{mg} / \mathrm{kg}$ [16].

\section{In vivo anti-asthmatic activity}

Histamine induced bronchoconstriction in guinea pig $[17,18]$

Overnight fasted guinea pigs were divided into three groups $(n=6)$. Before drug treatment, each animal was placed in the histamine chamber and exposed to $0.2 \% \mathrm{w} / \mathrm{v}$ histamine aerosol. Pre convulsive time (PCT) was defined as the time of exposure to the onset of dyspnea leading to the appearance of pre convulsive dyspnea (PCD). As soon as the PCD was detected, the animal was removed from the chamber and 


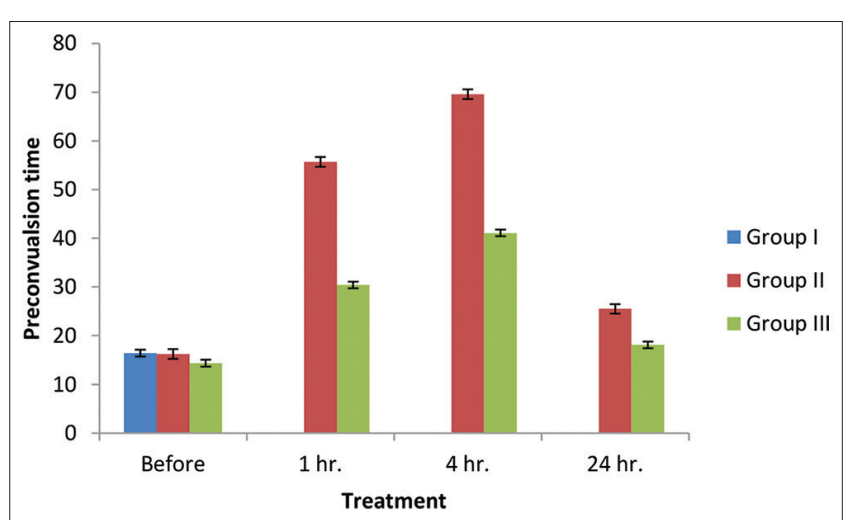

Fig. 1: Effect of ethanolic extracts of Capparis decidua on histamine-induced bronchoconstriction in guinea pigs. Group-I (Control): Aerosolized Histamine $(\mathbf{0 . 2 \%}$ w/v). Group-II (Std.): Aerosolized Histamine $(0.2 \% \mathrm{w} / \mathrm{v})+$ Chlorpheniramine meleate ( $2 \mathrm{mg} / \mathrm{kg}$, i.p.). Group-III (Test): Aerosolized Histamine (0.2\% w/v) + Ethanolic extract of Capparis decidua $(200 \mathrm{mg} / \mathrm{kg}$, p.o.)

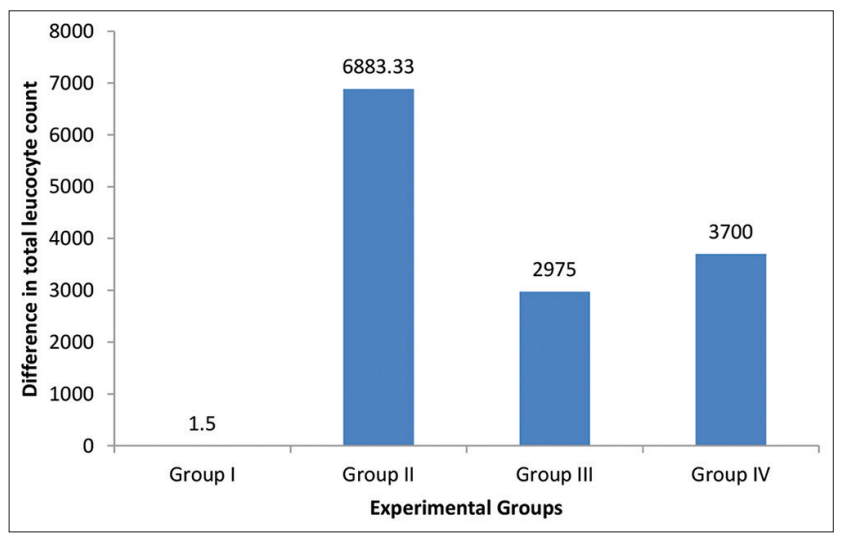

Fig. 2: Effect of ethanolic extracts of Capparis decidua on milkinduced leukocytosis in mice. Group-I (Normal control): Distilled water $10 \mathrm{~mL} / \mathrm{kg}$, p.o. Group-II (Positive control): Boiled and cooled milk ( $4 \mathrm{~mL} / \mathrm{kg}$, s.c.). Group-III (Std.): Dexamethasone $(50 \mathrm{mg} / \mathrm{kg}$, i.p.) + Boiled \& cooled milk ( $4 \mathrm{~mL} / \mathrm{kg}$, s.c.). Group-IV (Test): Boiled and cooled milk ( $4 \mathrm{~mL} / \mathrm{kg}$, s.c.) + Ethanolic extract of $C$. decidua $(200 \mathrm{mg} / \mathrm{kg}$, p.o.)

placed in the air. After $24 \mathrm{~h}$, the animals belonging to Group I served as control and were treated with a phosphate buffer $(1 \mathrm{~mL} / \mathrm{kg}$, p.o.); animals belonging to Group II were treated with Chlorpheniramine maleate $(2 \mathrm{mg} / \mathrm{kg}$, i.p.) while Group III was received a respective dose of ethanolic extract of $C$. decidua. These animals were also subjected to histamine aerosol overtime during the $1^{\text {st }}, 4^{\text {th }}$, and $24^{\text {th }} \mathrm{h}$ of drug administration, and PCT was determined again. The protection offered by treatment was calculated using the following formula:

$\%$ protection $=\left(1-\mathrm{T}_{1} / \mathrm{T}_{2}\right) \times 100$

$\mathrm{T}_{1}=$ The mean of PCT before administration of test drugs.

$\mathrm{T}_{2}=$ The mean of PCT after administering of test drugs at 1,4 , and $24 \mathrm{~h}$.

Milk induced leukocytosis in mice [19,20]

Mice were divided into four groups, six animals per group. An animal part of Group-I received $10 \mathrm{~mL} / \mathrm{kg}$ (p.o) of distilled water. Animal Groups II, III, and IV received an injection of boiled and cooled milk at a dose of $4 \mathrm{~mL} / \mathrm{kg}$, s.c. An animal belonging to Group III acted as standard and was received dexamethasone in a dose of $50 \mathrm{mg} / \mathrm{kg}$, i.p. Animal belonging to Group IV acted as test group and received a respective amount of ethanolic extract of $C$. decidua and after $1 \mathrm{~h}$ boiled and cooled milk ( $4 \mathrm{~mL} / \mathrm{kg}$, s.c.) was administered to the same animals. After $24 \mathrm{~h}$, blood samples were collected from all animals in their tail vein. Total leukocytes count was done in each group $24 \mathrm{~h}$ after injection of milk.

\section{Statistical analysis}

The results of various studies were exposed as mean \pm SEM and analyzed statistically using one-way ANOVA followed by Dunnett's test. ${ }^{*} \mathrm{p}<0.01$, ${ }^{* *} \mathrm{p}<0.05$ were considered significant.

\section{RESULTS}

Phytochemical investigation

Phytochemical study of ethanolic extracts of $C$. decidua has shown the presence of carbohydrate, alkaloids, flavonoids, glycosides, tannin, polyphenols, and steroids, whereas the phytochemical analysis of chloroform, and benzene extracts of the plant $C$. decidua have shown carbohydrate and protein. Petroleum ether extract has shown fixed oils and fats.

Histamine induced bronchoconstriction in Guinea pigs

The guinea pigs, when exposed to $0.2 \% \mathrm{w} / \mathrm{v}$ histamine aerosol, showed signs of persistent dyspnea leading to convulsions. Guinea pigs treated with chlorpheniramine maleate $(2 \mathrm{mg} / \mathrm{kg}$, i.p.) increased the PCD at $1^{\text {st }}, 4^{\text {th }}$, and $24^{\text {th }} \mathrm{h}$ compared to control. In the groups of guinea pigs pretreated with ethanolic extract of $C$. decidua $(200 \mathrm{mg} / \mathrm{kg}$, p.o.) increased the PCD at $1^{\text {st }}, 4^{\text {th }}$, and $24^{\text {th }} \mathrm{h}$ compared to control. Ethanolic extract of $C$. decidua $(200 \mathrm{mg} / \mathrm{kg}$, p.o.) shows an increase in percent protection, but percent protection was found to be lower than chlorpheniramine maleate $(2 \mathrm{mg} / \mathrm{kg}$, i.p).

Milk-induced leukocytosis in mice

Subcutaneous injection of milk at a dose of $4 \mathrm{~mL} / \mathrm{kg}$ produced an increase in the leukocytes count after $24 \mathrm{~h}$ of its administration. Mice treated with dexamethasone $(50 \mathrm{mg} / \mathrm{kg}$, i.p.), has shown inhibition of milk-induced leukocytosis as compared to positive control. In the groups of mice pretreated with ethanolic extract of C. decidua $(200 \mathrm{mg} / \mathrm{kg}, \mathrm{p.o})$, there was inhibition of milk-induced leukocytosis, but inhibition of leukocytosis was found to be less than dexamethasone (50 mg/kg, i.p.).

\section{DISCUSSION}

The present study is designed to test the anti-asthmatic activity of $C$. decidua. C. decidua is usually very high in alkaloids, tannins, glycosides, and flavonoids, etc. C. decidua appears to be a good plant for the treatment of bronchial asthma due to its reported anti-allergic activity, anti-inflammatory, and anti-oxidant activity.

Phytochemical tests of $C$. decidua have shown the presence of flavonoids, alkaloids, glycosides, steroids, tannins, triterpenoids, amino acids, etc., which have anti-asthmatic activity of the plants.

Guinea pigs exposed to histamine aerosol showed persistent dyspnea, that is, difficulty in breathing, leading to convulsions. In the present study, ethanolic treatment extracted from $C$. decidua showed significant prolongation in convulsive dyspnea time, but prolongation was found to be less as compared to standard chlorpheniramine maleate. The effect may be due to its inhibition of $\mathrm{H}_{1}$ - receptor or bronchodilating activity and may thus contribute to the regulation of asthma.

The present study of $C$. decidua was evaluated for the management of asthma using milk-induced leukocytosis in mice. Different types of mediators are involved in the pathology of asthma. It was shown that subcutaneous administration of milk produces a significant increase in leukocyte counts after $24 \mathrm{~h}$ of administration. Leukocyte during asthmatic inflammation release inflammatory mediators such as cytokines, histamine, and major essential protein, promoting the occurrence of inflammation. Leukocyte infiltration increases the inflammatory process through the by releasing of reactive oxygen species in the surrounding tissue, leading to increased oxidative stress and is associated with many pathogenic factors of asthma. 


\section{CONCLUSION}

In the present study, various chemical tests confirmed the presence of alkaloids, flavanoids, steroids, glycosides, tannins, and saponins in the ethanolic extract of $C$. decidua. They have been the action of smooth muscle relaxant, a bronchodilator, antioxidant, anti-inflammatory, mast cell stabilizing, anti-allergic, and antihistaminic activity.

Ethanolic extract of $C$. decidua shows the anti-asthmatic activity against bronchoconstriction induced by histamine. In the present study, the antihistaminic drugs chlorpheniramine maleate and ethanolic extract from $C$. decidua protected guinea pigs against histamine-induced bronchospasm. Ethanolic extract of $C$. deciduas significantly increases the latent period of convulsions compared to control. This indicates the utility of the ethanolic extract of $C$. decidua in treating asthma by, under its $\mathrm{H}_{1}$ - receptor blocking or bronchodilating activity.

This study shows that ethanolic extract of $C$. decidua suppresses the milk-induced leukocytosis by stabilizing the oxidative stress in the surrounding tissue. Mainly the leukocytes are responsible for releasing several inflammatory mediators such as histamine and cytokines which enhance thee inflammatory process. Infiltration of leucocytes in surrounding tissues in asthmatic inflammation causes increased oxidative stress, which is characterized as the main pathogenic feature of asthma. This study observed that the inhibition of leukocytosis was significant in mice treated with ethanolic extract of $C$. decidua as compared to the control group.

Ethanolic extract of $C$. decidua may possess anti-asthmatic activity, which may be due to antihistaminic activity, bronchodilating activity, mast cell stabilizing activity, anti-inflammatory activity, anti-allergic activity, anti-spasmodic activity, and anti-oxidant activity. All over, we can say that the ethanolic extract of $C$. decidua has significant antiasthmatic activity.

\section{ACKNOWLEDGMENTS}

I would like to express my deepest and sincere gratitude to my research supervisor Dr. Jai Singh Vaghela, Associate Professor, B.N College of Pharmacy, Udaipur, for the continuous support of my research, with his patience, inspiration, enthusiasm, and his vast knowledge. His guidance helped me throughout my research. I could not have imagined having a better advisor and mentor for my research. I am profusely thankful to him.

\section{AUTHORS CONTRIBUTIONS}

All authors have an equal share in the current research work.

\section{CONFLICT OF INTEREST}

By this, we declare that there is no conflict of interest.

\section{ATHORS FUNDING}

The present research work is funded by B.N University, Udaipur.

\section{REFERENCES}

1. Limbasiya KK, Modi VR, Tirgar PR. Evaluation of antiasthmatic activity of dried whole plant extract of Leucas aspera using various experimental animal models. Int J Phyto 2012;3:291-8.

2. Bhatt S, Upadhyay U, Upadhyay S. Evaluation of acute toxicity study and anti-asthmatic activity of zeal herbal granules. Int Res J Pharm 2013;4:213-5.

3. Patrick N. In vivo and in vitro anti-asthmatic effects of dichloromethane crude extract from the leaves of Labisia pumila. Global J Pharmacol 2012;6:126-30.

4. Chakraborty B, Datta R. Anti-inflammatory and anti-asthmatic activities of Alangium lamarkii (Alangiaceae). J Adv Pharm Educ Res 2013;3:524-30.

5. Anuradha A. Epidemiological study on bronchial asthma. Indian $\mathbf{J}$ Allergy Asthma Immunol 2011;25:85-9.

6. Kanderi MB, Khalaf T. Evaluation of asthma clinic in pharmacy care in Kuwait. Eur J Gen Med 2006;3:159-66.

7. Available from: http://www.chestjournal.chestpubs.org/content/130/1_ suppl/4S.full.html

8. Dhakad PK, Sharma PK. A Review on ethnobiological and medicinal potential of capparaceae family: Capparis decidua (forssk.) Edgew. Adv Pharmacol Pharm 2016;4:27-39.

9. Singh P, Mishra G, Sangeeta. Traditional uses, phytochemistry and pharmacological properties of Capparis decidua: An overiew. Scholars Res Lib 2011;3:71-82.

10. Abdalranman AA, Tigani SE. Biological activity of extracts from Capparis deciduas L. twigs. J Med Plants Res 2016;10:875-89.

11. Promila. Phytochemical and Pharmacological aspects of Capparis decidua (Forsk.): A review. Int J Appl Res 2016;2:467-72.

12. Dipti, Jaiswal ML. Kartra-an impotant medicinal plant of aride zone. Int J Ayu Pceutical Chem 2016;6:120-30.

13. Chishty S, Monika B. Medicinal and nutritional importance of Capparis decidua (Forssk.) Edgew. (Capparaceae). Int J Sci Res 2017;5:2319-64.

14. Godara D, Kaushik V. A method of isolation of capparisterol from capparis decidua and antinephrolithiasis activity. Am J Adv Drug Deliv 2015;3:86-95.

15. Rathee S, Rathee P, Rathee D. Phytochemical and pharmacological potential of Kair (Capparis Decidua). Int J Phytomed 2010;2:10-7.

16. OECD Guideline for the Testing of Chemical: Acute Oral Toxicityacute Toxic Class Method. Paris, France: OECD; 2001. p. 423.

17. Genwa C, Gilhotra UK, Verma AK. Evaluation of Citrullus colocynthis fruit. Int J Pharm Sci Res 2017;8:716-21.

18. Suralkar A, Gaikwad KK. Evaluation of antihistaminic activity of Sida rhombifolia Linn in management of allergic asthma. Int J Inst Pharm Life Sci 2014;4:322-32.

19. Singhal HK, Neetu. A review on anti-asthmatic activity of ayurvedic herbs. Global J Res Med Plants Indigen Med 2013;2:785-95.

20. Dogral KS, Chauhan S. Assessment of Indian medicinal plants for the treatment of asthma. J Med Plants Res 2015;9:851-62.

21. Kokate CK. Practical Pharmacognosy. $5^{\text {th }}$ ed. New Delhi: Vallabh Prakashan; 2014 